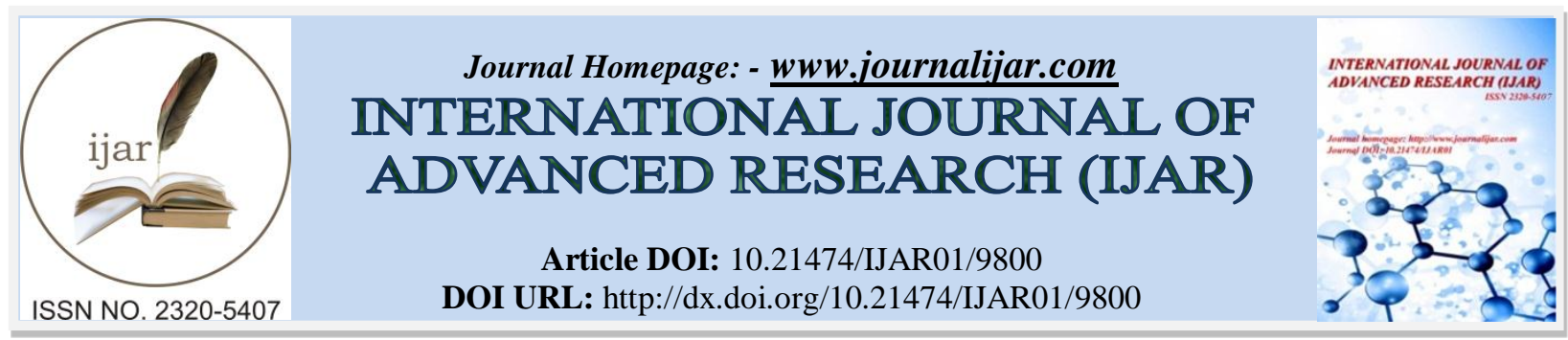

RESEARCH ARTICLE

\title{
ANDROPOGON GAYANUS KUNTH FORAGE PRODUCTION AND NUTRITIVE VALUES UNDER DIFFERENT CUTTING INTERVALS IN SOUTH REGION OF BENIN.
}

\begin{abstract}
Adjolohoun S.
Faculté des Sciences agronomiques, Université d'Abomey-calavi, Département des Productions Animales, 03 BP: 2819 Jéricho Cotonou (Bénin).
\end{abstract}

\section{Manuscript Info}

Manuscript History

Received: 02 August 2019

Final Accepted: 04 September 2019

Published: October 2019

Key words:-

Gamba grass, accessions, yield, crude protein, mineral contents, Benin.

\begin{abstract}
The grassland resource could be better managed if the effect of different defoliation regimes on the amount of the dry matter and nutritive value was known. Consequently, 9 accessions of Andropogon gayanus Kunth were evaluated in south region of Benin with an average $1100 \mathrm{~mm}$ annual rainfall during 3 years for ley pasture without any fertiliser input. Three cutting regimes (3-10-3, 5-6-5 and 6-4-6week) were tested for dry matter production (DM), crude protein $(\mathrm{CP})$ content, $\mathrm{CP}$ production and mineral $(\mathrm{Ca}, \mathrm{Mg}, \mathrm{P}, \mathrm{K}, \mathrm{Na}, \mathrm{Zn}, \mathrm{Mn}, \mathrm{Cu}$ and Co) contents. Significant differences were observed between accessions $(p<0.05)$, cutting regimes $(p<0.05)$ and years $(p<0.05)$ for DM and CP production. Accession and cutting regime influenced significantly $\mathrm{CP}$ content $(\mathrm{p}<0.05)$ but year had no influence. Forage harvested from 3$10-3$-week regime produced significantly $(\mathrm{p}<0.05)$ more DM $(4742 \mathrm{~kg}$ $\mathrm{DMha}^{-1}$ ) than 5-6-5-week (3635 $\mathrm{kg} \mathrm{DMha}^{-1}$ ) or 6-4-6-week cutting regime (3789 kg DMha ${ }^{-1}$ ). But the reverse effect was observed for CP content as 3-10-3-week regime (5.68 $\left.\mathrm{gkg}^{-1} \mathrm{DM}\right)$ had significantly $(\mathrm{p}<0.05)$ lower CP than those of 5-6-5-week $\left(8.55 \mathrm{gkg}^{-1} \mathrm{DM}\right)$ or 6-4-6week cutting regimes $\left(7.15 \mathrm{gkg}^{-1} \mathrm{DM}\right)$. Mineral concentrations varied between accessions but not by cutting regimes and years. Three accessions $\left(\mathrm{n}^{\circ} 1,4\right.$ and 5$)$ consistently outproduced than others and can be harvested through 5-6-5-week cutting regime. $\mathrm{P}, \mathrm{Na}, \mathrm{Zn}$ and $\mathrm{Cu}$ deficiencies were the most common detected in the cropped forages.
\end{abstract}

Copy Right, IJAR, 2019,. All rights reserved.

\section{Introduction:-}

In savanna region of West Africa, agriculture is facing increasing pressure as a result of continuing increases in both human and livestock populations. In this region, inadequate supply of feeds is the bottleneck to livestock production. Basically, this situation is related to the dependence of livestock raising on naturally available feed resources and little development of forage crops for feeding to animals. One of the alternatives to improve livestock feeding, and thereby productivity, could be the cultivation of productive nutritious forages to be offered during critical periods of the production cycle of animals when other sources of feeds are in short supply. In most of the cases, pasture grasses in the tropics cannot satisfy even the minimum requirement of nutrients of animals due to harvesting or grazing at advanced stage of maturity. Pastures rapidly decrease in acceptability and digestibility, particularly with crude protein (CP) as low as $2-3 \%$ in some periods of the year (Teka et al., 2005) and this is far below the minimum CP requirement of $7-8 \%$ for livestock maintenance (Coleman et al., 2003). There is a need for pasture species with 
high dry matter (DM) production and quality in order to enhance livestock productivity in grazing or cut-and-carry system. In both systems, one of the main issues to be addressed is how often to use forage for better DM production and quality forage. Several studies have been conducted to test the effect of age of cutting on both yield and quality factors. Babatoundé (2005), Onyeonagu (2012), Adjolohoun et al. (2013) and Gbenou et al. (2018) commented that cutting frequency was the major factor that influenced the DM production and nitrogen concentration of grasses. Generally, studies conducted on the effect of cutting frequency on plant DM production showed that the more infrequent cutting, the higher the DM yields but the crude protein concentration and the proportion of digestible forage dropped correspondingly. Even if most of these studies have reported positive increasing effect of cutting interval on DM production and the adverse effect on harvested forage quality, some authors have pointed out some variation between species and even between accessions in the same species. For example, in Venezuela, Morillo et al. (1997) had tested three cutting frequencies (28, 42 and 56 days) and reported that P. maximum forage yield was not influenced by cutting interval but $\mathrm{CP}$ concentration and mineral nutrients of the plant were affected. Studying the influence of cutting frequency on three P. virgatum cultivars in Canada, Madakadze et al. (1999) reported significant cultivar*cutting interval interaction, suggesting that, in the same species, different clipping schedules should be recommended for cultivars. In North of Benin, work of Michiels et al. (2000) reported that, P. maximum forage crude protein content increased simultaneously with DM production from the beginning of the rainy season up to about 4 weeks and after decreased sharply up to about 8 weeks following the onset of the rainy season. These results showed that the effects of cutting intervals on grass forage DM production and quality vary and need a caseby-case study for each variety or accession and region.

In West Africa, pasture species evaluation with the objective of identifying the most productive and adapted species has been of interest for some years (Michiels et al., 2000 ; Buldgen et al., 2001; Babatoundé, 2005 ; Adjolohoun et al., 2013). Most of these species concerned exotic plants such as Pennisetum purpureum, Brachiaria. ruziziensis, Centrosema pubescens, Stylosanthes hamata and Aeschynomene histrix. Very few studies were conducted on autochthonous species such as Andropogon gayanus accessions which could have a potential for animal production. The aim of this study was to identify A. gayanus accessions and cutting regimes which could both maximizing forage production and nutritive values on low fertility soils in order to provide recommendations on accessions and cuttings management to smallholder farmers.

\section{Material and methods:- Site description}

The experiment was conducted near Sègbohouè, located in Kpomassè region $\left(7^{\circ} 60^{\prime} \mathrm{N}, 2^{\circ} 54^{\prime} \mathrm{E}\right)$, in southern Benin during 3 rainy seasons (2016-2018). The region has a sub-humid climate with a long term annual rainfall of 1100 $\mathrm{mm}$ and a bimodal distribution lasting from March-October with peaks in June and September. Annual rainfall in the region during the period of the experiment is 1200, 1105 and 1058. Minimum and maximum temperatures are observed in December (dry and cold season) and March (dry and hot season) with $19-20{ }^{\circ} \mathrm{C}$ and $30-33{ }^{\circ} \mathrm{C}$, respectively. Soil at the experimental site was sandy ( $89 \%$ sand) with a $\mathrm{pH}$ of 6.0 , organic carbon $0.8 \%$, nitrogen $0.08 \%$ and $\mathrm{P}$ (extractable) $=8 \mathrm{ppm}$. Other mineral element concentrations were $0.9 \mathrm{cmol} / \mathrm{kg}$ for potassium and sodium, $1.6 \mathrm{cmol} / \mathrm{kg}$ for magnesium and $3.5 \mathrm{cmol} / \mathrm{kg}$ for calcium, giving an effective cation exchange capacity (ECEC) of $6.5 \mathrm{cmol} / \mathrm{kg}$.

\section{Culture establishment, DM and CP production evaluation}

\section{Some characteristics of $\mathbf{A}$. gayanus accessions for this experiment are presented in table 1.}

Table 1 summarizes some morphologic and agronomic traits of these accessions. The site was ploughed and harrowed before planting in $7 \mathrm{~m} \times 7 \mathrm{~m}\left(49 \mathrm{~m}^{2}\right)$ plots separated from each other by a $2-\mathrm{m}$ band. The nine A. gayanus accessions were established at the beginning of raining season in 2016 at $40-\mathrm{cm}$ spacing (optimal density) using crown splits (4-5 tillers/hole). During the 3 experimental years, weeding was done manually with hand hoes. The following three cutting regimes were tested: 3-10-3, 5-6-5 and 6-4-6-week giving a constant period evaluation of 16 weeks for each cutting regime during each three years. They were chosen as a combination of four commonly cutting intervals to simulate grazing system (3 to 6-week interval) or a possible interval (10-week) in hay production systems. Treatment was a combination of each accession with cutting regime and was replicated 4 times, giving a total of $9 \times 3 \times 4=108$ plots arranged in a complete randomised block design. Three weeks after planting, all the plots were cut back to a suitable height of $15 \mathrm{~cm}$ (standardization cut to promote a uniform stand) without recording biomass production data. Thereafter, a given cutting regime affected to each plot was applied and at the appropriate cutting date. Three quadrats of $1 \times 1 \mathrm{~m}$ were randomly chosen in each plot and harvested at $15 \mathrm{~cm}$ above soil level using a sickle and immediately weighed. After each harvest, the residual biomass of the plots was cut to the same 
height and removed. Afterwards, forage from the 3 quadrats of each plot was bulked and 2 samples (approximately $200 \mathrm{~g}$ ) were taken from each plot and oven-dried for $48-72 \mathrm{~h}$ at $60{ }^{\circ} \mathrm{C}$ and weighed for dry matter content and yield determination. These 2 samples were bulked per plot and ground through a $1-\mathrm{mm}$ screen prior and analysed for CP (Kjeldahl-method, $\mathrm{N} \times 6.25)$. The DM production data over 16 weeks for each year was obtained by combining yields of the 3 harvest intervals of each cutting regime (3-10-3, 5-6-5 and 6-4-6-week) in each year. Forage CP content and CP production per ha were calculated for each year and treatment on the basis of the contribution of each cutting to total DM of the year. Standardization cuts were done each year at the beginning of raining season and harvested material was discarded.

\section{Macro- and micro-nutrients determination}

All samples harvested for each accession were pooled within years for each regime cutting on the basis of their contribution to total dry matter recorded in the year. Pooled samples were used to measure mineral concentrations. $\mathrm{Ca}, \mathrm{Mg}, \mathrm{K}, \mathrm{Na}, \mathrm{Zn}, \mathrm{Mn}, \mathrm{Cu}$ and $\mathrm{Co}$ concentrations were determined by atomic absorption spectrophotometry using a Perkin Elmer AAS-800 (Wellesley, MA). P was determined by the colorimetric method using Molybdovanadate reagent.

\section{Statistical analysis:-}

Means and standard error of means on DM production per ha, CP content and CP production per ha data were calculated for $n=4$ for each treatment and year. The means were classified by the Differences of Least Square Means method using the MIXED procedure of the SAS 8.02 software (SAS Inc, Cary, NC, USA) with the following model: $A=\mu+E i+C j+Y k+\left(E^{*} C\right) i j+\left(E^{*} Y\right) i k+\left(C^{*} Y\right) j k+\left(E^{*} C^{*} Y\right) i j k+e i j k l$.

Where $\mathrm{A}$ is the result of the measurement, $\mu=$ overall mean, Ei = accession effect $(\mathrm{i}=1,2, \ldots, 9), \mathrm{Cj}=$ cutting regime effect $(\mathrm{i}=1,2,3), \mathrm{Yk}=$ year effect $(\mathrm{k}=1,2,3)$, and their above two or three way interactions. The term eijkl = experimental error. When significant interaction occurred, the data were reanalysed separately by two- or one-way analysis of variance. Mineral content data were analysed through the following model: $\mathrm{B}=\varepsilon+\mathrm{Mi}+\mathrm{Nj}+$ $\left(\mathrm{M}^{*} \mathrm{~N}\right) \mathrm{ij}+$ eijk. Where $\mathrm{B}$ is the result of the measurement, $\varepsilon=$ overall mean, $\mathrm{Mi}=$ accession effect $(\mathrm{i}=1,2, \ldots, 9), \mathrm{Nj}$ = cutting regime effect $(\mathrm{i}=1,2,3)$ and $\left(\mathrm{M}^{*} \mathrm{~N}\right) \mathrm{ij}$ their interaction. A $\mathrm{p}<0.05$ level of significance was used to separate means

\section{Results:-}

\section{Dry matter, crude protein content and crude protein production}

DM production data of tested accessions are presented in Table 2. There was significant difference between accessions $(\mathrm{p}<0.05)$, cutting regimes $(\mathrm{p}<0.05)$ and years $(\mathrm{p}<0.05)$ (Table 3$)$. DM production averaged across accession, cutting regime and year was $4055 \mathrm{~kg} \mathrm{ha}^{-1} \mathrm{year}^{-1}$ (not showed in table 2). Averaged over accessions, accession 4 was the most productive $\left(7871 \mathrm{~kg} \mathrm{ha}^{-1} \mathrm{year}^{-1}\right.$, not showed in table 2). DM production of accession 5 $\left(5630 \mathrm{~kg} \mathrm{ha}^{-1} \mathrm{year}^{-1}\right)$ and accession $1\left(5587 \mathrm{~kg} \mathrm{ha}^{-1} \mathrm{year}^{-1}\right)$ were significantly lower than that of accession 4 . DM production of accession 9 (3734 kg ha year $\left.^{-1}\right)$, accession 2 (3439 kg ha ${ }^{-1}$ year $\left.^{-1}\right)$, accession $8\left(3201 \mathrm{~kg} \mathrm{ha}^{-1} \mathrm{year}^{-1}\right)$, accession 6 (2806 kg ha year $\left.^{-1}\right)$ and accession 3 (2639 kg ha $\mathrm{kear}^{-1}$ ) were not significantly different $(\mathrm{p}>0.05)($ not showed in table 2). Accession 7 produced the lowest DM (1589 kg ha ${ }^{-1}$ year $\left.^{-1}\right)$. Over cutting regimes, 3-10-3-week cutting regime had produced (4742 $\mathrm{kg} \mathrm{ha}^{-1} \mathrm{year}^{-1}$ ) significantly ( $\left.\mathrm{p}<0.05\right)$ more than the two others (4-6-4- and 5-65-week with 3789 and $3635 \mathrm{~kg} \mathrm{ha}^{-1}$ year $^{-1}$, respectively). There is no significant difference between DM productions of 4-6-4- and 5-6-5-week cutting regimes. The two or three-way interactions were not significant except for accession*year $(\mathrm{P}=0.013)$ (Table 3).Through accessions and cutting regimes, year $1\left(4742 \mathrm{~kg} \mathrm{ha}^{-1} \mathrm{year}^{-1}\right) \mathrm{produced}^{-1}$ significantly $(\mathrm{p}<0.05)$ more DM than year $2\left(3789 \mathrm{~kg} \mathrm{ha}^{-1} \mathrm{year}^{-1}\right)$ and year $3\left(3635 \mathrm{~kg} \mathrm{ha}^{-1} \mathrm{year}^{-1}\right)$. A decrease in DM production was observed for all accessions during the three year experiments but the extent of decrease varied largely according to accessions. Accession 1 was less affected by DM decreasing. In year 3, this accession produced $64 \%$ of the forage yield in year 1 but other accessions produced only between 25 and $50 \%$ of their DM yielded in year 1 .

Crude protein concentrations of tested accessions were presented in table 4. There was significant difference between accessions $(\mathrm{p}<0.05)$ and cutting regimes $(\mathrm{p}<0.01)$ for $\mathrm{CP}$ content but year effect was not significant $(\mathrm{p}>$ 0.05) (Table 3). Cutting regime influenced more significantly forage crude protein content than accession. $\mathrm{CP}$ per ha is presented in table 5. It was significantly influenced by accession, cutting regime and year (table 3).

Mineral concentrations 
Among tested plants, accession 7 appeared to be more concentrated for macronutrients content (Table 6). Its forage ash content was the highest and represented 1.5 to 2.6 times those of others accessions. Its $\mathrm{P}$ content was 1.8 to 2.9 times as compared to others. Its $\mathrm{Mg}$ and $\mathrm{K}$ contents were the highest of all. Accessions 1, 4 and 8 showed the lowest $\mathrm{Ca}$ concentrations. All accessions had similar Na concentrations. For micro-nutrients, significant differences were observed between accessions for $\mathrm{Zn}, \mathrm{Mn}$ and $\mathrm{Cu}$. However accessions didn't differ significantly in Co content (Table 6).

\section{Discussions:-}

Dry matter production, crude protein content and crude protein production

Despite that all accessions belong to the same species, significant difference $(\mathrm{p}<0.05)$ for DM production appeared between them across cutting regimes and years, showing that they react differently toward these parameters. Therefore, there are great possibilities for choosing some of them for increasing animal feeds in West Africa region. Accession 4 was consistently the highest and accession 7 the lowest yielder. The superior yield of accession 4 at all harvest regimes may be a function of its better soil nutrients or water use (Pieterse et al., 1997; Adjolohoun et al., 2008; Buldgen and Dieng, 1997, Buldgen et al., 2001). On the other hand, accession 4 was reported by Adjolohoun (in press) to have more leaves than others. This intrinsic trait of this accession can allow it to have more surface area and therefore more photosynthesis activity due to more solar irradiance quantity which could be intercepted. This particular characteristic can contribute to its higher DM production (Alejandra et al., 1997; Buldgen and Dieng, 1997). A decrease in dry matter production was observed through the years for all tested accessions. This could be explained by low soil fertility, non-input nutrient to soil during three years harvesting and, probably, a rainfall decreasing through three year experiments. A decrease in DM production has been reported in others studies in the area (Adjolohoun et al., 2008). Out of these nine accessions, accession 9 had a lesser DM decreasing, showing its better adaptation to environment conditions prevailing in the testing area.

There were no significant accession*cutting regime interaction $(\mathrm{p}=0.663)$ for DM production. This result shows that cutting regime influence through accessions for DM was similar for all nine tested accessions. This result is interesting and of practical implication as it allows for suggesting to small farmers the same cutting regime independently to accessions or harvesting year. Cutting regime of 3-10-3-week had produced constantly the highest dry matter. Nevertheless, all of forages harvested according to this regime had between $5-6 \mathrm{~g} \mathrm{CPkg}^{-1} \mathrm{DM}$ and therefore, less than 7-8 $\mathrm{g} \mathrm{CPkg}^{-1} \mathrm{DM}$ required by Minson (1990) and Coleman et al. (2003) for adequate ruminant nutrition. Such forages with low CP content will limit micro-organism activities in the rumen and therefore induce slow rate of digestion. This would result in decreased DM intake and reduced animal performance. So, cutting regime of 3-10-3-week, even if it allows the highest dry matter production couldn't be recommended to farmers.

\section{Minerals concentration of forages}

Accession 5 forage concentrations in Ca are more than three times that of accession 8 . All of forage concentrations in $\mathrm{Ca}$ are above the requirements levels of $2.4 \mathrm{~g} / \mathrm{kg}$ (Rivière 1991) except for accession 8 (2.08 g/ $\mathrm{kg})$. Herbage Ca is used very efficiently by cattle when necessary and an average forage $\mathrm{Ca}$ absorbability of 0.68 can be exceeded (AFRC, 1991) for tested accessions. The highest level of $7.21 \mathrm{~g} / \mathrm{kg}$ obtained with accession 5 can suggest a possible toxicity for sheep, but $\mathrm{Ca}$ is not generally regarded as a toxic element, because homeostatic mechanisms ensure that excess dietary $\mathrm{Ca}$ is extensively excreted in faeces (Underwood et al.1999). P forage concentrations $(0.62-1.81 \mathrm{~g} / \mathrm{kg}$ $\mathrm{DM})$ recorded in this trial were lower than that reported for P. maximum cv Mulate (2.5 g/kg DM) (Pieterse et al., 1997) but, forage $\mathrm{P}$ of accession $7(1.81 \mathrm{~g} / \mathrm{kg} \mathrm{DM})$ compared well with those noted for P. maximum cv Petrie, Gatton and Vencidor (1.7-1.8 g/kgDM) reported by Pieterse et al. (1997). Deficiency for P is the most common nutritional mineral problem for the tested accessions in the area (Adjolohoun et al., 2008, Adjolohoun et al., 2013), probably due to the low $\mathrm{P}$ levels in soils. $\mathrm{P}$ supplementation would be necessary for animal feeding in the area. Under the same environmental and growing conditions, concentration in P forage of accession 7 was more than 3 fold that of accession 2 showing the possibility of choosing maximum A. gayanus accession that could have an important contribution for herbivorous $\mathrm{P}$ diet for this region. $\mathrm{K}$ concentrations of tested forages were largely above the critical values for deficiency suggested for grazing ruminants and summarized by (NRC, 2000). Except for accession 7, forage $\mathrm{Mg}$ contents observed in this study were in the range 1.05-1.97 $\mathrm{g} / \mathrm{kg}$ DM. They were lower than the range of 2.4-3.9 g/kg DM reported for P. maximum cv. Gatton by Davison et al., (1987). Except for accessions 4 and 6 , forage $\mathrm{Mg}$ content differences were lower to meet animal requirements, specially for pregnant and lacting cattle which need 1.4-2.1 $\mathrm{g} \mathrm{kg}^{-1} \mathrm{DM}$ (Sultte, 1983). The low concentrations of forage in $\mathrm{Na}, \mathrm{Zn}$ and $\mathrm{Cu}$ need a provision of mineral supplements when the forages are solely used in animal feeding. 


\section{Conclusion:-}

gayanus is one of the important forage species in West Africa. This study had produced valuable findings as it demonstrated an useful great variability in potentials between tested accessions for dry matter and nutritious forage production never reported among indigenous accessions of this species. Such investigations should be continued to increase this species germplasm availability for improving ruminant nutrition in West Africa. Under the conditions of this experiment, it can be concluded that accessions 1, 4 and 5 are the most interested for both dry matter and crude protein production. Among the 3 cutting regimes tested, 5-6-5-week regime could be recommended for maximizing both quantity and quality forage production. In general, forage of tested accessions had adequate $\mathrm{Ca}, \mathrm{K}$, $\mathrm{Mg}$ and Co contents for satisfying livestock dietary maintenance requirement. However, forages need to be complemented for $\mathrm{P}, \mathrm{Zn}$ and $\mathrm{Cu}$ for good animal production. Due to variation in the area conditions and their effects on plant production, we suggest that the study should be continued in others environments. On another hand, the accessions were chosen and tested for their use by farmers as ley pastures under low input conditions. Therefore, the study should be followed by complementary work on the influence of these accessions on soil nutrients depletion after three years cultivation without fertilizer input.

Tableau 1:-Some morphologic, agronomic and physiologic traits of tested Andropogon gayanus accessions

\begin{tabular}{|c|c|c|c|c|c|c|c|c|c|}
\hline \multirow[t]{2}{*}{ Traits } & \multicolumn{9}{|c|}{ Accession } \\
\hline & 1 & 2 & 3 & 4 & 5 & 6 & 7 & 8 & 9 \\
\hline \multicolumn{10}{|l|}{ Morphologic } \\
\hline Plant height $(\mathrm{cm})$ & 123 & 178 & 271 & 166 & 258 & 328 & 430 & 359 & 233 \\
\hline Leave length $(\mathrm{cm})$ & 47 & 59 & 66 & 51 & 76 & 87 & 107 & 93 & 55 \\
\hline Leave wide (mm) & 25 & 32 & 37 & 26 & 34 & 37 & 42 & 38 & 37 \\
\hline Tiller per stuff (unity) & 33 & 49 & 43 & 57 & 48 & 52 & 44 & 64 & 77 \\
\hline Tiller diameter $(\mathrm{mm})$ & 7 & 6 & 5 & 5 & 6 & 5 & 6 & 4 & 4 \\
\hline $\begin{array}{l}\text { Stuff diameter at } 75 \mathrm{~cm} \\
\text { above soil level }(\mathrm{cm})\end{array}$ & 40 & 40 & 53 & 57 & 53 & 58 & 52 & 59 & 69 \\
\hline Panicle length $(\mathrm{cm})$ & 38 & 41 & 39 & 46 & 60 & 74 & 114 & 95 & 39 \\
\hline \multicolumn{10}{|l|}{ Agronomic } \\
\hline Leaf/stem (ratio) & 1.35 & 1.18 & 1.0 & 1.02 & 0.99 & 0.91 & 1.05 & 0.99 & 0.75 \\
\hline $\begin{array}{l}\text { Leave number/tiller } \\
\text { (unity) }\end{array}$ & 7.6 & 7.5 & 7.4 & 12.0 & 8.6 & 9.4 & 8.0 & 9.5 & 8.0 \\
\hline
\end{tabular}


Table 2:-Dry mater yield $\left(\mathrm{kgha}^{-1}\right)$ of 9 Andropogon gayanus local accessions under 3 cutting regimes during three years

\begin{tabular}{|c|c|c|c|c|c|c|c|c|c|}
\hline & \multicolumn{9}{|c|}{ Year } \\
\hline Accession & & 2009 & & & 2010 & & & 2011 & \\
\hline & $3-10-3$ & $5-6-5$ & $6-4-6$ & $3-10-3$ & $5-6-5$ & $6-4-6$ & $3-10-3$ & $5-6-5$ & $6-4-6$ \\
\hline $\begin{array}{c}\text { Accession } \\
1\end{array}$ & $\begin{array}{c}5403 \\
\text { Acd }^{(1)}\end{array}$ & $\begin{array}{c}4104 \\
\text { Acd }\end{array}$ & $\begin{array}{c}4218 \\
\text { Ac }\end{array}$ & $4341 \mathrm{Bc}$ & $3322 \mathrm{Bc}$ & $\begin{array}{c}3434 \\
\mathrm{Bc}\end{array}$ & $\begin{array}{c}3377 \\
\mathrm{Cc}\end{array}$ & $\begin{array}{c}2602 \\
\mathrm{Cb}\end{array}$ & $\begin{array}{c}2808 \\
\mathrm{Cb}\end{array}$ \\
\hline $\begin{array}{c}\text { Accession } \\
2\end{array}$ & 5531 Acd & $\begin{array}{l}4786 \\
\text { Acd }\end{array}$ & $\begin{array}{c}4987 \\
\mathrm{Ac}\end{array}$ & $3965 \mathrm{Bcd}$ & $3105 \mathrm{Bc}$ & $\begin{array}{c}3260 \\
\mathrm{Bc}\end{array}$ & $\begin{array}{c}2144 \\
\mathrm{Cd}\end{array}$ & $\begin{array}{l}1599 \\
\mathrm{Cbc}\end{array}$ & $\begin{array}{l}1571 \\
\text { Ccd }\end{array}$ \\
\hline $\begin{array}{c}\text { Accession } \\
3\end{array}$ & $4177 \mathrm{Ae}$ & $\begin{array}{c}3845 \\
\mathrm{Ad}\end{array}$ & $\begin{array}{c}4065 \\
\text { Ac }\end{array}$ & $3014 \mathrm{Bd}$ & $\begin{array}{c}2594 \\
\text { Bcd }\end{array}$ & $\begin{array}{c}2468 \\
B d\end{array}$ & $\begin{array}{c}1451 \\
\mathrm{Ce}\end{array}$ & $\begin{array}{l}1065 \\
\text { Ccd }\end{array}$ & $\begin{array}{c}1076 \\
\mathrm{Cd}\end{array}$ \\
\hline $\begin{array}{c}\text { Accession } \\
4\end{array}$ & $11106 \mathrm{Aa}$ & $\begin{array}{c}9689 \\
\text { Aa }\end{array}$ & $\begin{array}{c}9887 \\
\mathrm{Aa}\end{array}$ & $9567 \mathrm{Ba}$ & $7109 \mathrm{Ba}$ & $\begin{array}{c}8210 \\
\mathrm{Ba}\end{array}$ & $\begin{array}{c}6045 \\
\mathrm{Ca}\end{array}$ & $\begin{array}{c}4539 \\
\mathrm{Ca}\end{array}$ & $\begin{array}{c}4687 \\
\mathrm{Ca}\end{array}$ \\
\hline $\begin{array}{c}\text { Accession } \\
5\end{array}$ & $9400 \mathrm{Ab}$ & $\begin{array}{c}7999 \\
\mathrm{Ab}\end{array}$ & $\begin{array}{c}8056 \\
\mathrm{Ab}\end{array}$ & $6509 \mathrm{Bb}$ & $4472 \mathrm{Bb}$ & $\begin{array}{c}4656 \\
\mathrm{Bb}\end{array}$ & $\begin{array}{c}4443 \\
\mathrm{Cb}\end{array}$ & $\begin{array}{c}2305 \\
\mathrm{Cb}\end{array}$ & $\begin{array}{c}2800 \\
\mathrm{Cb}\end{array}$ \\
\hline $\begin{array}{c}\text { Accession } \\
6\end{array}$ & $4277 \mathrm{Ae}$ & $\begin{array}{c}3590 \\
\text { Ad }\end{array}$ & $\begin{array}{c}3806 \\
\text { Ac }\end{array}$ & $3200 \mathrm{Bd}$ & $2506 \mathrm{Be}$ & $\begin{array}{c}2697 \\
\text { Bde }\end{array}$ & $\begin{array}{c}2199 \\
\mathrm{Cd}\end{array}$ & $\begin{array}{c}1475 \\
\mathrm{Cc}\end{array}$ & $\begin{array}{l}1500 \\
\text { Ccd }\end{array}$ \\
\hline $\begin{array}{c}\text { Accession } \\
7\end{array}$ & $3136 \mathrm{Ae}$ & $\begin{array}{c}2139 \\
\mathrm{Ae}\end{array}$ & $\begin{array}{c}2560 \\
\mathrm{Ad}\end{array}$ & $2056 \mathrm{Bd}$ & $985 \mathrm{Be}$ & $\begin{array}{c}1290 \\
\mathrm{Be}\end{array}$ & $910 \mathrm{Ce}$ & $405 \mathrm{Cd}$ & $820 \mathrm{Cd}$ \\
\hline $\begin{array}{c}\text { Accession } \\
8 \\
\end{array}$ & $6560 \mathrm{Ac}$ & $\begin{array}{c}5256 \\
\text { Ac }\end{array}$ & $\begin{array}{c}4945 \\
\text { Ac }\end{array}$ & $3502 \mathrm{Bcd}$ & $2076 \mathrm{Bd}$ & $\begin{array}{c}2301 \\
\mathrm{Bd}\end{array}$ & $\begin{array}{c}2015 \\
\mathrm{Cd}\end{array}$ & $910 \mathrm{Cd}$ & $\begin{array}{c}1243 \\
\mathrm{Cd}\end{array}$ \\
\hline $\begin{array}{c}\text { Accession } \\
9\end{array}$ & $\begin{array}{c}10023 \\
\mathrm{Aab}\end{array}$ & $\begin{array}{c}8643 \\
\text { Aab }\end{array}$ & $\begin{array}{c}7780 \\
\mathrm{Ab}\end{array}$ & $6134 \mathrm{Bb}$ & $4967 \mathrm{Bb}$ & $\begin{array}{c}5060 \\
\mathrm{Bb}\end{array}$ & $\begin{array}{c}3541 \\
\mathrm{Cc}\end{array}$ & $\begin{array}{l}2051 \\
\mathrm{Cbc}\end{array}$ & $\begin{array}{c}2080 \\
\mathrm{Cc}\end{array}$ \\
\hline Mean & 6624 & 5561 & 5593 & 4699 & 3460 & 3708 & 2903 & 1883 & 2065 \\
\hline SEM & 557 & 521 & 485 & 439 & 346 & 414 & 346 & 224 & 242 \\
\hline
\end{tabular}

(1) Values within a column followed by the same lower case letter do not differ significantly $(p<0.05)$. For the same cutting regime and for the same accession, values followed by the same upper case letter do not differ significantly $(\mathrm{p}<0.05)$.

Tableau 3:-Results of a 3-way ANOVA (GLM) showing the significance of accessions (9 accessions), cutting regimes (3-10-3-week, 6-5-6-week, 5-6-5-week), year $(2009,2010,2011)$ and their interactions on dry matter production, crude protein content and crude protein production

\begin{tabular}{|l|c|c|c|}
\hline Effect & Dry matter yield & Crude protein content & Crude protein yield \\
\hline Accession & $<0.05$ & 0.037 & 0.013 \\
\hline Cutting regime & $<0.05$ & 0.017 & 0.015 \\
\hline Year & $<0.05$ & 0.601 & 0.003 \\
\hline Accession×cutting regime & 0.663 & 0.097 & 0.232 \\
\hline Accession×Year & 0.013 & 0.261 & 0.076 \\
\hline Cutting regimexyear & 0.720 & 0.321 & 0.231 \\
\hline Accession×cutting regimexyear & 0.874 & 0.881 & 0.695 \\
\hline
\end{tabular}


Table 4:-Crude protein concentrations of 9 Andropogon gayanus local accessions under 3 cutting regimes

\begin{tabular}{|c|c|c|c|c|c|c|c|c|c|c|}
\hline \multirow{2}{*}{$\begin{array}{l}\text { Cutting } \\
\text { regime }\end{array}$} & \multicolumn{9}{|c|}{ Accession } & \multirow[t]{2}{*}{ Mean } \\
\hline & 1 & 2 & 3 & 4 & 5 & 6 & 7 & 8 & 9 & \\
\hline $3-10-3$ & $\begin{array}{c}5.41 \\
\mathrm{ABc}^{(1)}\end{array}$ & $\begin{array}{l}5,80 \\
\mathrm{ABc}\end{array}$ & $\begin{array}{l}5,24 \\
\mathrm{ABc}\end{array}$ & $\begin{array}{l}5,76 \\
\mathrm{ABc}\end{array}$ & $\begin{array}{l}5,23 \\
\mathrm{ABc}\end{array}$ & $\begin{array}{c}5,02 \\
\mathrm{Bc}\end{array}$ & $\begin{array}{l}5,95 \\
\mathrm{ABc}\end{array}$ & $\begin{array}{c}6,01 \\
\text { Ac }\end{array}$ & $\begin{array}{l}6.00 \\
\mathrm{ABc}\end{array}$ & 5,68 \\
\hline $5-6-5$ & $8,66 \mathrm{Ba}$ & $\begin{array}{l}8,76 \\
\mathrm{ABa}\end{array}$ & $\begin{array}{l}9,00 \\
\mathrm{ABa}\end{array}$ & $\begin{array}{l}8,99 \\
\mathrm{ABa} \\
\end{array}$ & $\begin{array}{l}8,55 \\
\mathrm{BCa} \\
\end{array}$ & $\begin{array}{c}7,34 \\
\mathrm{Ca} \\
\end{array}$ & $\begin{array}{l}8,89 \\
\mathrm{ABa}\end{array}$ & $\begin{array}{c}9,64 \\
\mathrm{Aa} \\
\end{array}$ & $\begin{array}{c}8,07 \\
\mathrm{Ba} \\
\end{array}$ & 8,55 \\
\hline $6-4-6$ & $7.01 \mathrm{Bb}$ & $\begin{array}{c}6,98 \\
\mathrm{Bb} \\
\end{array}$ & $\begin{array}{c}7,55 \\
\mathrm{Bb} \\
\end{array}$ & $\begin{array}{l}8,03 \\
\mathrm{ABb} \\
\end{array}$ & $\begin{array}{l}7,85 \\
\mathrm{ABb} \\
\end{array}$ & $\begin{array}{c}6,89 \\
\mathrm{Bb} \\
\end{array}$ & $\begin{array}{c}7,44 \\
\mathrm{Bb} \\
\end{array}$ & $\begin{array}{c}8,32 \\
\mathrm{Ab} \\
\end{array}$ & $\begin{array}{c}7.00 \\
\mathrm{Bb} \\
\end{array}$ & 7,15 \\
\hline Mean & 7.03 & 7.18 & 7.26 & 7.59 & 7.21 & 6.42 & 7.43 & 7.99 & 7,02 & 7,12 \\
\hline SEM & 0.22 & 0.21 & 0.26 & 0.23 & 0.24 & 0.17 & 0.20 & 0.25 & 0.14 & 0,13 \\
\hline
\end{tabular}

(1) Values within a column followed by the same lower case letter do not differ significantly $(\mathrm{p}<0.05)$. In the same line, values followed by the same upper case letter do not differ significantly $(\mathrm{p}<0.05)$.

Table 5:-Crude protein production per ha of 9 Andropogon gayanus local accessions under 3 cutting regimes (x-y-zweek) during 2008, 2009 and 2010.

\begin{tabular}{|c|c|c|c|c|c|c|c|c|c|}
\hline \multirow[t]{3}{*}{ Accession } & \multicolumn{9}{|c|}{ Year } \\
\hline & \multicolumn{3}{|c|}{2008} & \multicolumn{3}{|c|}{2009} & \multicolumn{3}{|c|}{2010} \\
\hline & $3-10-3$ & $5-6-5$ & $6-5-6$ & $3-10-3$ & $5-6-5$ & $6-5-6$ & $3-10-3$ & $5-6-5$ & $6-5-6$ \\
\hline $\begin{array}{c}\text { Accession } \\
1\end{array}$ & $292 \mathrm{Ad}$ & $355 \mathrm{Ae}$ & $296 \mathrm{Af}$ & $235 \mathrm{Bc}$ & $287 \mathrm{Bc}$ & $241 \mathrm{Bc}$ & $\begin{array}{l}182 \\
\mathrm{Cbc}\end{array}$ & $225 \mathrm{Cb}$ & $197 \mathrm{Cb}$ \\
\hline $\begin{array}{c}\text { Accession } \\
2\end{array}$ & $321 \mathrm{Ad}$ & $419 \mathrm{Ad}$ & $348 \mathrm{Ae}$ & $230 \mathrm{Bc}$ & $272 \mathrm{Bc}$ & $227 \mathrm{Bcd}$ & $125 \mathrm{Cc}$ & $\begin{array}{l}140 \\
\text { Ccd }\end{array}$ & $110 \mathrm{Cc}$ \\
\hline $\begin{array}{c}\text { Accession } \\
3 \\
\end{array}$ & $219 \mathrm{Ae}$ & $346 \mathrm{Ae}$ & $\begin{array}{l}307 \\
\text { Aef }\end{array}$ & $158 \mathrm{Bd}$ & $\begin{array}{l}234 \\
\text { Bcd }\end{array}$ & 186 Bde & $76 \mathrm{Cde}$ & $96 \mathrm{Cde}$ & $82 \mathrm{Cd}$ \\
\hline $\begin{array}{c}\text { Accession } \\
4\end{array}$ & $640 \mathrm{Aa}$ & $871 \mathrm{Aa}$ & $791 \mathrm{Aa}$ & $551 \mathrm{Ba}$ & $639 \mathrm{Ba}$ & $657 \mathrm{Ba}$ & $348 \mathrm{Ca}$ & $408 \mathrm{Ca}$ & $375 \mathrm{Ca}$ \\
\hline $\begin{array}{c}\text { Accession } \\
5 \\
\end{array}$ & $492 \mathrm{Ab}$ & $684 \mathrm{Ab}$ & $635 \mathrm{Ab}$ & $340 \mathrm{Bb}$ & $383 \mathrm{Bb}$ & $366 \mathrm{Bb}$ & $232 \mathrm{Cb}$ & $\begin{array}{l}197 \\
\mathrm{Cbc}\end{array}$ & $220 \mathrm{Cb}$ \\
\hline $\begin{array}{c}\text { Accession } \\
6 \\
\end{array}$ & $215 \mathrm{Ae}$ & $264 \mathrm{Af}$ & $262 \mathrm{Af}$ & $161 \mathrm{Bd}$ & $\begin{array}{l}184 \\
\text { Bde } \\
\end{array}$ & $187 \mathrm{Be}$ & $\begin{array}{l}111 \\
\text { Ccd } \\
\end{array}$ & $108 \mathrm{Ce}$ & $103 \mathrm{Cc}$ \\
\hline $\begin{array}{c}\text { Accession } \\
7\end{array}$ & $187 \mathrm{Ae}$ & $190 \mathrm{Af}$ & $190 \mathrm{Ag}$ & $122 \mathrm{Bd}$ & $88 \mathrm{Be}$ & $96 \mathrm{Bf}$ & $54 \mathrm{Ce}$ & $45 \mathrm{Cf}$ & $61 \mathrm{Cd}$ \\
\hline $\begin{array}{c}\text { Accession } \\
8 \\
\end{array}$ & $394 \mathrm{Ac}$ & $507 \mathrm{Ac}$ & $411 \mathrm{Ad}$ & $211 \mathrm{Bc}$ & $200 \mathrm{Bd}$ & $192 \mathrm{Bd}$ & $121 \mathrm{Cc}$ & $88 \mathrm{Cde}$ & $104 \mathrm{Cc}$ \\
\hline $\begin{array}{c}\text { Accession } \\
9 \\
\end{array}$ & $601 \mathrm{Aa}$ & $698 \mathrm{Ab}$ & $544 \mathrm{Ac}$ & $368 \mathrm{Bb}$ & $401 \mathrm{Bb}$ & $354 \mathrm{Bb}$ & $213 \mathrm{Cb}$ & $\begin{array}{l}165 \\
\text { Ccd }\end{array}$ & $146 \mathrm{Cc}$ \\
\hline Mean & 373 & 482 & 421 & 264 & 299 & 278 & 163 & 165 & 155 \\
\hline SEM & 33 & 45 & 38 & 25 & 30 & 33 & 20 & 21 & 19 \\
\hline
\end{tabular}

(1) Values within a column followed by the same lower case letter do not differ significantly $(\mathrm{p}<0.05)$. For the same cutting regime and for the same line, values followed by the same upper case letter do not differ significantly $(\mathrm{p}<0.05)$. 
Table 6:-Macro- and micro-mineral concentrations of Andropogon gayanus accessions compared with ruminant needs $(\mathrm{n}=3)^{*}$.

\begin{tabular}{|c|c|c|c|c|c|c|c|c|c|c|}
\hline \multirow[t]{3}{*}{ Accession } & \multirow{2}{*}{ Ash } & \multicolumn{5}{|c|}{ Macro-minerals } & \multicolumn{4}{|c|}{ Micro-minerals } \\
\hline & & $\mathrm{Ca}$ & $\mathrm{P}$ & $\mathrm{Mg}$ & K & $\mathrm{Na}$ & $\mathrm{Zn}$ & $\mathrm{Cu}$ & $\mathrm{Mn}$ & Co \\
\hline & (\% DM) & \multicolumn{5}{|c|}{ (g/kg DM) } & \multicolumn{4}{|c|}{$(\mathrm{mg} / \mathrm{kgDM})$} \\
\hline Accession 1 & $5.77 \mathrm{e}^{(1)}$ & $6.66 \mathrm{a}$ & $0.62 \mathrm{e}$ & $1.97 \mathrm{~b}$ & $10.59 \mathrm{~b}$ & $0.1 \mathrm{a}$ & $14 \mathrm{~b}$ & $3 \mathrm{~b}$ & $81 \mathrm{ab}$ & $0.1 \mathrm{a}$ \\
\hline Accession 2 & $9.05 \mathrm{~b}$ & $6.61 \mathrm{a}$ & $0.59 \mathrm{e}$ & $1.89 \mathrm{~b}$ & $8.46 \mathrm{c}$ & $0.2 \mathrm{a}$ & $12 \mathrm{~b}$ & $6 \mathrm{a}$ & $75 \mathrm{bc}$ & $0.1 \mathrm{a}$ \\
\hline Accession 3 & $7.43 \mathrm{~cd}$ & $5.55 \mathrm{~b}$ & $\begin{array}{c}0.92 \\
b c\end{array}$ & $1.40 \mathrm{c}$ & $7.98 \mathrm{c}$ & $0.1 \mathrm{a}$ & $16 \mathrm{ab}$ & $5 a b$ & $66 c$ & $0.1 \mathrm{a}$ \\
\hline Accession 4 & $5.90 \mathrm{e}$ & $5.95 \mathrm{~b}$ & $0.87 \mathrm{c}$ & $1.05 \mathrm{c}$ & $9.04 \mathrm{c}$ & $0.1 \mathrm{a}$ & $15 \mathrm{ab}$ & $4 \mathrm{~b}$ & $88 \mathrm{ab}$ & $0.1 \mathrm{a}$ \\
\hline Accession 5 & $10.01 \mathrm{~b}$ & $7.21 \mathrm{a}$ & $\begin{array}{c}0.65 \\
\text { de }\end{array}$ & $1.93 \mathrm{~b}$ & $10.88 \mathrm{~b}$ & $0.2 \mathrm{a}$ & $16 \mathrm{ab}$ & $7 \mathrm{a}$ & $80 \mathrm{ab}$ & $0.2 \mathrm{a}$ \\
\hline Accession 6 & $6.66 \mathrm{de}$ & $\begin{array}{c}6.01 \\
a b\end{array}$ & $1.01 \mathrm{~b}$ & $1.07 \mathrm{c}$ & $12.02 \mathrm{~b}$ & $0.1 \mathrm{a}$ & $15 \mathrm{ab}$ & $4 \mathrm{~b}$ & $91 \mathrm{a}$ & $0.1 \mathrm{a}$ \\
\hline Accession 7 & $15.09 \mathrm{a}$ & $5.98 \mathrm{~b}$ & $1.81 \mathrm{a}$ & $2.65 \mathrm{a}$ & $21.6 \mathrm{a}$ & $0.1 \mathrm{a}$ & $20 \mathrm{a}$ & $5 \mathrm{ab}$ & $77 \mathrm{~b}$ & $0.1 \mathrm{a}$ \\
\hline Accession 8 & $5.78 \mathrm{e}$ & $2.08 \mathrm{~d}$ & $\begin{array}{c}0.77 \\
\mathrm{~cd}\end{array}$ & $1.91 \mathrm{~b}$ & $8.21 \mathrm{c}$ & $0.1 \mathrm{a}$ & $17 \mathrm{ab}$ & $4 \mathrm{~b}$ & $69 \mathrm{c}$ & $0.1 \mathrm{a}$ \\
\hline Accession 9 & $8.55 \mathrm{bc}$ & $3.76 \mathrm{c}$ & $0.79 \mathrm{c}$ & $1.36 \mathrm{c}$ & $10.55 \mathrm{c}$ & $0.1 \mathrm{a}$ & $18 \mathrm{a}$ & $3 \mathrm{~b}$ & $65 \mathrm{c}$ & $0.1 \mathrm{a}$ \\
\hline Mean & 8.25 & 5.87 & 0.86 & 1.69 & 11.04 & 0.1 & 16 & 5 & 77 & 0.1 \\
\hline SEM & 3.2 & 1.01 & 0.3 & 0.8 & 9 & 0.0 & 4 & 0.5 & 14 & 0.0 \\
\hline $\begin{array}{c}\text { Ruminant } \\
\text { needs }{ }^{(2)}\end{array}$ & - & 2.4 & 1.2 & 1.2 & $6-8$ & 0.7 & 50 & 10 & 50 & 0.1 \\
\hline
\end{tabular}

${ }^{(1)}$ Values within a column followed by the same case letter do not differ significantly $(\mathrm{p}<0.05)$. Cutting regime had no significant effect on accession mineral concentrations and therefore, only means through accession are presented.

${ }^{(2)}$ Requirements for cattle (200 kg LWt) with average liveweight gain of $100 \mathrm{~g} / \mathrm{d}$ (Rivière 1991) for Ca, P and S;

NRC (2000) for K, Na and Underwood and Suttle (1999) for Mg.

\section{References:-}

1. Adjolohoun, S. (2008): Yield, nutritive value and effects on soil fertility of forage grasses and legumes cultivated as ley pastures in the Borgou region of Benin. Thesis, Gembloux University, Belgium, 109p.

2. Adjolohoun, S., Buldgen, A., Adandedjan, C. Dardenne, P. and Decruyenaere, V. (2008a): Production and nutritive value of three grass species cultivated for ley pasture in the Borgou region of Benin. Trop. Grass. 42: 237-244.

3. Adjolohoun, S., Buldgen, A., Adandedjan, C., Decruyenaere, V. and Dardenne, P. (2008b): Yield and nutritive value of herbaceous and browse forage legumes in the Borgou region of Benin. Trop. Grass. 42: 104 - 111.

4. Adjolohoun, S., Dahouda, M., Adandédjan, C., Toléba, SS., Kindomihou, V. and Sinsin, B. (2013): Evaluation of biomass production and nutritive value of nine Panicum maximum accessions in Central region of Benin. AJAR 8(17), 1661-1668.

5. AFRC, (1991): Technical Committee on Responses to Nutrients Report No. 6. A reappraisal of the calcium and phosphorus requirements of sheep and cattle. Nutrition Abstracts and Reviews 61, 573-612.

6. Alejandra, P., Maria, E., González, O., Villasmil, J.J. (1997): Acclimation of Panicum maximum to different light regimes. Effect of subsequent defoliation. Rev. Fac. Agron. 14: 625-639.

7. Babatoundé, S., (2005): Etude et prédiction de la valeur alimentaire de graminées et de légumineuses fourragères en zone tropicale humide du Bénin. Thèse doct. Sci. Agron. Fac. Univ. Sci. Agron. Gembloux, Belgique, 165p.

8. Buldgen, A., Michiels, B., Adjolohoun, S., Adandédjan, C. (2001): Research note: Production and nutritive value of grasses cultivated in the coastal area of Benin. Trop. Grass. 35: 43-47.

9. Coleman, S.W., Hart, S.P. and Sahlu, T. (2003): Relationships among forage chemistry, rumination and retention time with intake and digestibility of hay by goats. Small Rum. Res. 50: 129-140.

10. Davison, T.M., Shepherd, R.K. and Brown, G.W. (1987): Influence of frequency of nitrogen fertilizer application on milk production from cow grazing tropical grass pasture. Trop. Grass. 21: 1-8. 
11. Madakadze, J.C., Stewart, K.A., Peterson, P.R., Coulman, B.E., Smith, D.L. (1999): Cutting frequency and nitrogen fertilization effects on yield and nitrogen concentration of switchgrass in a short season area. Crop Science 39: 552-557.

12. Michiels, B., Babatoundé, S., Lihounhinto, F., Chabi, S.L.V. and Buldgen, A (2000): Effect of season and concentrate feeding on the eating behaviour of sheep grazing a mixing pasture of Panicum maximum var. $\mathrm{C} 1$ and Brachiaria ruziziensis. Trop. Grass. 34: 48-55.

13. Minson, D.J. (1990): Forage in Ruminant Nutrition. Academic Press, Inc., San Diego, CA.

14. Morillo, D.E., Farìa-Mármol, J., Gonzalez, R. (1997): Effect of the cutting frequency on yield and crude protein and mineral contents of Panicum maximum. In: XVI International Grassland Congress, Jun, 8-19, Canada, session 22, Forage and Grassland Management, 61-62.

15. NRC, (2000): Nutrient requirements of beef cattle. 7th revised edn. Academy of Sciences. Available http://www.nap.edu/openbook/0309069343/html/54.html (verified on August 28 2019).

16. Onyeonagu, C.C., Anyadiegwu, O.A. and Uwalaka, T.K. (2012): The quality of crop fractions of a degraded Panicum maximum pasture under different cutting intervals and nitrogen fertilizer rates. AJAR, 7(14), 21742182

17. Pieterse, P.A., Rethman, N.F.G. and van Bosch (1997): Production, water use efficiency and quality of four cultivars of Panicum maximum at different levels of nitrogen fertilisation. Trop grass 31: 117-123.

18. Rivière, R. (1991) : Manuel d'alimentation des ruminants domestiques en milieu tropical. (IEMVT : Paris).

19. Teka, O., Van Onacker, J., Sinsin, B.A. and Lejoly, J. (2005):, Evaluation pastorale du ranch de Samiondji au Bénin. Bul. Rech. Agr. Bén. 48: 33-46.

20. Sultte, N.F. (1983): Assessment of the mineral and trace elements status of feeds. In. Feed Information and Animal Production. Proceedings of the Second Symposium of the International Network of Feed Information Centres. pp. 211-237. (Commonwealth Agricultural Bureaux: Farnham Royal).

21. Underwood, E.J. and Suttle N.F. (1999): Mineral nutrition of livestock, 3rd edn. (CAB International: UK. 